\title{
BIOMEDICINAL AND GASTROPROTECTIVE ASPECTS OF ORGANOBISMUTH COMPOUNDS: RECENT APPROACHES AND FUTURE PERSPECTIVES
}

\author{
SYED MISBAHUL HASAN ${ }^{1 *}$, SHIVBHADRA SINGH ${ }^{2,3}$, RAVI KANT ${ }^{2}$ \\ ${ }^{1}$ Department of Pharmaceutical Chemistry, Integral University, Lucknow, Uttar Pradesh, India. ${ }^{2}$ Helix BioGenesis, Pvt. Ltd., Noida, \\ Uttar Pradesh, India. ${ }^{3}$ Research Scholar, Integral University, Lucknow, Uttar Pradesh, India. Email: misbahhasan@yahoo.com
}

Received: 12 February 2019, Revised and Accepted: 03 April 2019

\section{ABSTRACT}

Objective: Peptic ulcer is a disease caused due to an imbalance of aggressive and defensive factors in the body. Helicobacter pylori infections and colonization are also associated strongly to the peptic ulcer disease. Bismuth-containing organic compounds have been attributed to a major influential role in the successful treatment of peptic ulcer by inhibiting gastric acid secretion and provide cytoprotective properties which result in ulcer healing. Hence, the objective of this review is to discuss recent approaches and future perspectives of organobismuth compounds in the treatment of peptic ulcer.

Results: A total of 112 papers were included in the review, among them 20 papers describe the pathophysiology of peptic ulcer, 10 papers discuss about diagnostic test for $\mathrm{H}$ pylori infection, 4 papers describe the drug regimen used in peptic ulcer treatment, 13 papers discuss about failure and alternative therapies for treatment of peptic ulcer, 8 papers describe the chemistry of bismuth, 20 papers discuss about mechanism of action of bismuth, 27 papers describe the newer bismuth complexes for H. pylori eradication, and 8 paper discuss about gastroprotective activity of bismuthcontaining derivatives.

Conclusion: Organobismuth compounds/drugs are effective to eradicate H. pylori in conjunction with antibiotics. It also provides gastroprotective action and dramatic decrease of relapse rate which accounts for further exploration of organobismuth compounds to pave new ways for the design and synthesis of novel compounds in the effective treatment of peptic ulcer.

Keywords: Peptic ulcer, Helicobacter pylori, Organobismuth drugs, Eradication, Gastroprotective.

(c) 2019 The Authors. Published by Innovare Academic Sciences Pvt Ltd. This is an open access article under the CC BY license (http://creativecommons. org/licenses/by/4. 0/) DOI: http://dx.doi.org/10.22159/ajpcr.2019.v12i5.32679

\section{INTRODUCTION}

The peptic ulcer disease (PUD) is mainly the development of gastric erosion or ulcers on various regions of the alimentary canal which occurs when there is an increase in acid and pepsin activity in gastric juice toward the mucosal barrier. It may be represented by a pseudo equation: PUD Imbalance between gastric acid secretion and mucosal defense mechanism

Factors including genetic and non-genetic are involved [1] which results in imbalance of aggressive factors (such as acid, pepsin, refluxed bile, leukotriene, and reactive oxygen species [ROS]) and defensive factors (mucus secretion and thickness, bicarbonate, mucosal prostaglandins, mucosal blood flow, mucosal repair and restitution, non-enzymatic and enzymatic antioxidants, and some other growth factors) [2,3] Nonsteroidal anti-inflammatory drugs (NSAIDs) and lowdose aspirin are also an increasingly important cause of ulcers and their complications [4,5]. Helicobacter pylori infections and colonization are also associated very strongly to the PUD [6] which results in an imbalance of aggressive and defensive factors. Hence, peptic ulcers can be classified as:

a) Ulcers due to hypersecretion of acid (Zollinger-Ellison syndrome).

b) Ulcers due to NSAIDs.

c) Ulcers which are integrated with H. pylori infection [7].

Risk factors from the environment [8], may increase the erosion to mucosal wall, include excessive drinking of alcohol [9], smoking [10,11] or chewing tobacco, emotional stress, and psychosocial factors $[12,13]$. Complications of PUD are hemorrhage, bleeding, perforation, and gastric outlet obstruction [14].

\section{H. PYLORI - A CENTRAL PATHOGENIC FACTOR IN PEPTIC ULCER}

Acid and pepsin are important factors in causing the erosion along with infections due to $H$. pylori, which is important as central pathogenic mechanism of ulcerogenesis, weakening the gastro duodenal defenses and altering somatostatin, gastrin and acid homeostasis [15]. H. pylori infects about $50 \%$ of the world's population due to adaptations thereby preventing detection by the immune system. It is a spiral to coccoidlike-shaped Gram-negative bacterium, having flagella which make it motile in viscous mucus in the stomach. It binds on epithelial gastric cells and causes a release of proteins from the outer membrane and also an expression of urease, catalase, and oxidase enabling the organism to survive in an acidic stomach environment. Acquisition of bacterium in humans occurs in childhood, the infection rate for either sex is similar [16] and if untreated then infection is lifelong [17]. The infection is mainly transmitted through the fecal-oral route in developing countries and gastro-oral route in developed countries [18]. Over $90 \%$ and $70 \%$ of duodenal ulcer (DU) and gastric ulcer (GU), respectively, are related to infection through $H$. pylori [19]. Fig. 1 explains the pathogenesis of peptic ulcer by the acquisition of H. pylori and other factors. H. pylori strains phenotypically can be divided into two groups; Type 1 contains vacuolating toxin, encoded by the gene vacA (94-kda vacA) and cytotoxin-associated protein encoded by the gene cagA (120-128-kcagA) and Type 2 contains non-cytotoxic vacA and cagA negative strains. It has been observed that Type 1 strains cause more intensive inflammation than Type-2 [20].

\section{ERADICATION THERAPY}

H. pylori eradication is the least expensive approach for curing ulcer disease [29] and also helps for the healing of both DU and GU. 


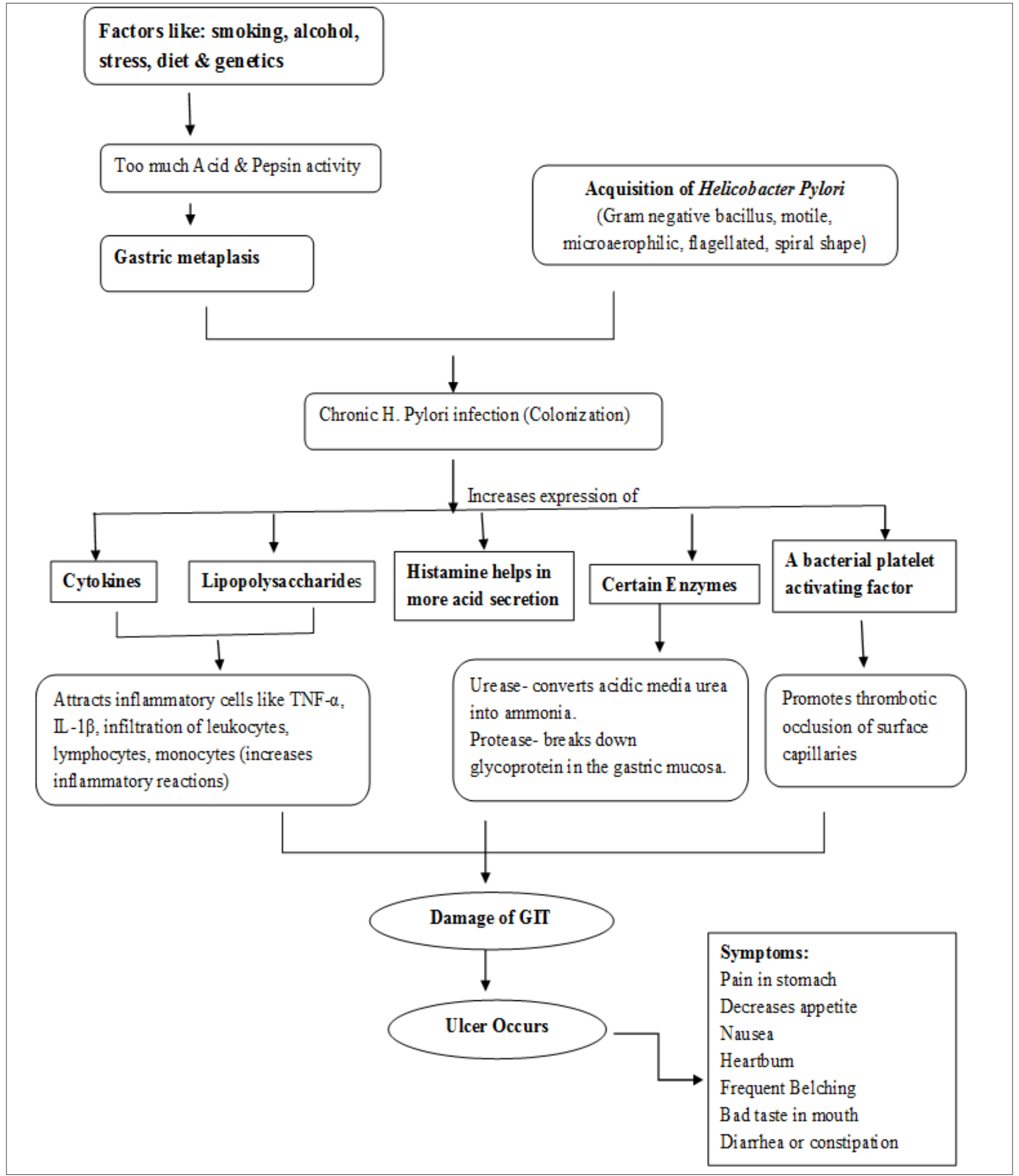

Fig. 1: Pathogenesis of peptic ulcer

Eradication also results in a dramatic decrease of relapse rate and maintain protein concentration in the stomach to normal. It also eliminates the need for maintenance therapy [30]. H. pylori infection is associated with gastric carcinogenesis and eradication can reduce the lifetime risk of gastric cancer. Tables 1 and 2 provides details of diagnostic test and drug regimen for H. pylori and Fig. 2 details about the structures of these reported drugs for eradication of $H$. pylori. Recommendation of $H$. pylori eradication is given for those patients who were suffering from PUD, gastric mucosa-associated lymphoid tissue lymphoma, atrophic gastritis, after gastric cancer resection, first-degree relative patients of gastric cancer, investigated non-ulcer dyspepsia, users of NSAIDs, unexplained iron deficiency anemia, etc. A different regimen of drugs including different categories of antibiotics, proton pump inhibitors (PPI), and bismuth-based drugs [31] are available for the eradication of H. pylori. 
The main reasons for eradication failure of $H$. pylori infection include antibiotic resistance, poor compliance, and rapid metabolism of PPI.

\section{FAILURE IN ERADICATION THERAPY}

The eradication therapy H. pylori is failed due to major reasons such as (a) rapid metabolism of PPI and (b) antibiotic resistance with the most commonly used antibiotic, clarithromycin. The resistance is unevenly distributed worldwide, resistance rates being higher in developed countries than in developing countries. A quinolone often used is levofloxacin for which resistance is also a concern. Development of resistance to these two important antibiotics can decrease the standard level of eradication from $90 \%$ to less. Other antibiotics used include metronidazole, amoxicillin, tetracycline, and rifampicin. Larger consumption of these antibiotics may also develop resistance resulting in decreased eradication rates (c) side effects of drugs leads to decreased patient compliance and (d) H. pylori can assume a resting coccoid form which is not susceptible to antibiotic treatment. The bacterium may remain inside the epithelial cell or in the stomach mucus layer limiting drug access. Hence, finding an alternative drug therapy which overcomes these problems is necessary. Various alternatives such as plant material [32], probiotics [33], peptides [34], polysaccharides [35], microorganisms, vaccines [36], and many more are explored. In this context, organobismuth drugs put forth an important role through a different mechanism of action like binding to proteins and enzymes interacting networks which provide prevention of $H$. pylori-associated diseases. Hence, it is required to explore more about organobismuth drugs which improve its solubility as well as pharmacokinetic and pharmacodynamic properties such that they are more effective. Table 3 provide details of enzymatic targets for organobismuth compounds.

\section{ALTERNATIVE THERAPIES OF ORGANOBISMUTH COMPOUNDS}

Bismuth-containing triple or quadruple therapy is an alternative line of the treatment for $H$. pylori infection $[37,38]$ because these are safe and exert local effects [39] and resistance to bismuth drugs has not been reported yet [40] for $H$. pylori or any other pathogenic microorganism. Bismuth can act as an antimicrobial agent toward H. pylori by suppressing them but do not eliminate it but when administered with antibiotics provide synergistic effects to the antibiotics. Hence, use of these drugs may also reduce the resistance risk of other coadministered antibiotics such as clarithromycin and metronidazole and slow down the relapse rate of $H$. pylori infection. Numerous different bismuth-based compounds are available, such as colloidal bismuth subcitrate [41] (colloidal bismuth subcitrate [CBS] used for dyspepsia, DU, and GU), bismuth subsalicylate (BSS used for traveler's diarrhea, dyspepsia, and H. pylori), bismuthsubnitrate (for gastric disorders, constipation, and irritable colon), and the newer ranitidine bismuth citrate [42,43] (RBC-for H. pylori, DU, and $\mathrm{GU}$ ). In addition, many bismuth nanotubes of novel bismuth compounds having different structures have been synthesized and are active toward the eradication of $H$. pylori by exerting different MOA. Its application in colloidal form and low dosage (below $0.5 \mathrm{~g} /$ day) reduces toxic side effects by reducing its absorption which excludes potential neurotoxicity [44]. In serum bismuth forms strong complexes with lactoferrin and transferrin and this phenomenon also play an important role for low toxicity [45]. Bismuth-containing medicaments are available in the form of colloidal suspensions, ointments, injectables, liquids, solves, and tablets.

\section{CHEMISTRY OF BISMUTH}

Bismuth is an element of Group 15 located in the bottom of the periodic table having an atomic number of 83 and atomic mass of 209 which is the only naturally occurring stable isotope. Bismuth is a soft, silvery metal with a bright surface and density of $9.78 \mathrm{~g} / \mathrm{cm}^{3}$. Although bismuth occurs naturally in earth crust in small quantities as a pure form, its crustal abundance is very low that is $8 p p b$ as it is reported as a $69^{\text {th }}$ abundant element and is less common than indium, cadmium, and only twice as common as gold [46]. The electronic configuration of [Xe] 4f145d106s26p3 allowing bismuth to accept an electron pair readily as well as the availability of unoccupied orbitals elevates its affinity to extend coordination. Two main oxidation states are found in nature $(+3$ example bismuth halides, BSS, etc., and +5 example bismuth (V) fluoride). It also found in the ore form in bismuthinite [47], bismuth glance $\left(\mathrm{Bi}_{2} \mathrm{~S}_{3}\right)$, bismuth ocher $\left(\mathrm{Bi}_{2} \mathrm{O}_{3}\right)$, and bismutite $\left[(\mathrm{BiO})_{2} \mathrm{CO}_{3} \cdot \mathrm{H} 2 \mathrm{O}\right]$ [48]. It is also found as a by-product in refining lead, copper [49], tin, silver, and gold. The metal exists in three allotropic forms, but the only rhombohedral form is stable. Its melting point is $271^{\circ} \mathrm{C}$ and its boiling point is $1560^{\circ} \mathrm{C}$ [50]. Bismuth in the oxidation state of +3 behaves like a Lewis acid when bonded to an electronegative atom and thus is used as an important catalyst for various industrial applications. Due to the Lewis acidic nature of the bismuth (III) center, additional intra- and inter-molecular bonds can develop and thereby result in extended coordination structures (coordination number is 3-10), for example, bismuth nitrate pentahydrate, [Bi(NO3)3.5H2O] exhibits a ten coordinate geometry around the bismuth (III) center. Compounds of bismuth (IV) [51] may exist and the solid state compounds of bismuth (V) - alkali metal bismuthates are also known. The ions of bismuth (V) do not exist in solution [52]. The bismuth (I) complex in the solution is available by dissolving metallic Bi in conc. hydrochloric acid; however, this solution is reported to be unstable [53]. In three coordinate triaryl and alkyl bismuth (III) compounds, the Bi (III) center obeys the octet rule resulting in a trigonal pyramidal coordination geometry, which is in agreement with the valence shell electron pair repulsion theory.

Bismuth-containing quadruple therapy is an alternative line of treatment for $H$. pylori infection recommend-ed.

\section{REPORTED MECHANISMS OF BISMUTH ACTION}

Bismuth disrupts multiple biological pathways of $H$. pylori such as tricarboxylic acid cycle, cell redox homeostasis, nickel homeostasis, protein folding, and iron homeostasis [54]. The MOA of bismuth against $H$. pylori have been reviewed and it is assumed that it may produce antimicrobial action by different complex mechanisms such as obstructions in the biological activity of enzymes produced by H. pylori, for example, urease, alcohol dehydrogenase (ADH), fumarate reductase, fumarase, and proteases (pepsin and phospholipase $C$ and A2) $[55,56]$. It affects the climate of the organism for its growth and hindrance of the union of H. pylori to surface epithelial cells [57]. Bismuth also exerts its mechanism by impediment of adenosine triphosphate adenosine triphosphate synthesis [58], retardation of protein, cell wall synthesis, and membrane function [59] through complex formation and a depletion in capsular polysaccharide production [60]. On the other side, it is also assumed that it inhibits gastric acid secretion [61] and provides cytoprotective [62] like properties which result in ulcer healing.

Bi present in organobismuth compounds can bind to intracellular proteins of $H$. pylori such as HspA, HspB, and NapA, it binds to heat shock protein-A $(\mathrm{HspA})$ protein of the bacterium and disrupts nickel homeostasis, is reported by metalloproteomic approach. HspA protein in the organism is essential for urease activation and urease is responsible for its survival in an acidic environment. Bismuth can binds to nickel in the histidine (His-) and cysteine Cys-rich metal binding domain at $\mathrm{C}$ terminus [67]. Iron metabolism pathway of $H$. pylori is also disrupted by $\mathrm{Bi}$ and was demonstrated through metallomics approach. Bismuth binds to ferric uptake regulator (fur) protein at S1 site, which increases protein oligomerization and there is loss of DNA binding power. It reduces transcriptions in regulated genes, which are pivotal for bacterial physiology $[68,69]$. Disruption of iron equanimity can also result in the production of ROS which produces oxidative stress in the bacterium leads to injury in DNA and membrane [70]. Membrane damage leads to bacterial autolysis. It upregulates the expression of protein thioredoxin which also leads to a high level of oxidative stress to the organism.

\section{Bismuth complexes with thiolate}

Bismuth (III) compounds binds strongly with thiolate sulfur, bismuth forms a coordinate bond with thiolate group of amino acid cysteine is predicted through infrared (IR) spectroscopy. Its simultaneous oral 
administration produces a remarkable rise in blood plasma bismuth. The complex $\left[\left(\mathrm{SC}\left(\mathrm{CH}_{3}\right)_{2} \mathrm{CH}\left(\mathrm{NH}_{2}\right) \mathrm{CO}_{2}\right] \mathrm{BiCl}\right.$ shows that chelation by sulfur, nitrogen, and oxygen of tridentate D-penicillamine reported through X-ray crystallography [71] bismuth also forms well-constructed complexes with the tripeptide glutathione and $\mathrm{N}$-acetyl-L-cysteine. Glutathione plays a crucial role in the transportation and distribution of bismuth (III) in cells and bio-fluids. As it is widely used for binding of Bi by hugepeptides and proteins. Each Bismuth (III) ion results in the cotransport of three molecules of glutathione. $1 \mathrm{H}$-nuclear magnetic resonance (NMR) studies reveal that Bi appears to pass slowly through cell membranes by a shuttle mechanism involving membrane proteins and forms an intracellular complex with glutathione (gsh) possibly $\left[\mathrm{Bi}(\mathrm{H}-1 \mathrm{gsh})_{3}\right]$

\section{Bismuth complexes with metallothionein}

Cell differentiation and proliferation are controlled by metallothionein protein. It helps to detoxicate metallic ions such as Cd (II), Hg (II), and $\mathrm{Au}$ (I), helps to subscribe $\mathrm{Zn}$ (II) to apo-enzymes, play a role in neurophysiology, and is a target for Bi (III) in the brain. The structure of metallothionein composed of two domains- $\alpha$ and $\beta$ having two metalthiolate clusters. Structures are predicted using X-ray crystallography and NMR by Shaw and Savas [72]. The $\alpha$-domain (C-terminal) contains 11 cysteine and forms a cluster of $4 \mathrm{Cd}$ or $\mathrm{Zn}$ ions bound to 5 bridging and 6 terminal cysteine thiolates. The $\beta$-domain ( $\mathrm{N}$-terminal) contains 9 cysteine and forms a cluster of $3 \mathrm{Cd}$ or $\mathrm{Zn}$ ions which is ligand by 3 bridging and 6 terminal cysteine thiolates. It is well known that bismuth, when administered with cisplatin can reduce the side effects because bismuth (III) is a potential inducer of metallothionein synthesis in the kidney. The strong affinity of bismuth to metallothionein in a ratio of 7:1 is due to bismuth higher affinity for thiolate ligands which are present in metallothionein.

\section{Bismuth binding to transferrin and lactoferrin}

Bismuth (III) binds relatively strongly to transferrin due to its high acidity. Transferrin is a glycoprotein which helps in transportation of iron in the blood. Lactoferrin is a similar kind of protein to transferrin and found in the mucus of human. Transferrin is only $30 \%$ bound to iron in blood so it can bind to other metals such as bi (III), Ga (III), and

Table 1: Diagnostic test for H. pylori infection

\begin{tabular}{|c|c|c|c|}
\hline Test division & Test name & Test description & Reference \\
\hline \multirow[t]{5}{*}{ Test with endoscopy } & RUT & $\mathrm{pH}$ of the biopsy specimen is measured (if alkaline shows the presence) & [21] \\
\hline & Bacterial culture & $\begin{array}{l}\text { Determination of antibiotic sensitivities by the development of culture of the } \\
\text { microorganism }\end{array}$ & {$[22]$} \\
\hline & Histology & Provide auxiliary information on degree and pattern of inflammation & {$[23]$} \\
\hline & FISH & Localization and identification of H. pylori & [24] \\
\hline & Molecular approach: PCR & Very sensitive and less time consuming (DNA probe technology) & {$[25]$} \\
\hline \multirow[t]{5}{*}{ Test without endoscopy } & SAT & Examination of the stool to check the presence of $H$. pylori & [26] \\
\hline & Finger-stick serology test & H. pylori-specific IgG antibodies presence is checked & \\
\hline & Whole blood serology & H. pylori-specific IgG antibodies presence is checked & [27] \\
\hline & $13 \mathrm{C}$-urea breath test & Urea metabolism principle is used for $H$. pylori eradication analysis & [28] \\
\hline & $14 \mathrm{C}$-urea breath test & Urea metabolism principle is used for $H$. pylori eradication analysis & \\
\hline
\end{tabular}

RUT: Rapid urease test, FISH: Fluorescence in situ hybridization, PCR: Polymerase chain reaction, SAT: Stool antigen test, H. pylori: Helicobacter pylori

Table 2: Drug regimen for H. pylori eradication

\begin{tabular}{|c|c|c|c|}
\hline S. No. & Therapy & Drug category & Drug example \\
\hline 1. & Monotherapy & Antibiotics, H2RA, or Bismuth compounds & $\begin{array}{l}\text { Clarithromycin (2), ranitidine (4), famotidine (5), nizatidine (6) or } \\
\text { CBS (11), RBC }\end{array}$ \\
\hline 2. & Dual therapy & $\begin{array}{l}\text { Two antibiotics, PPI+antibiotics or } \\
\text { Bismuth+antibiotics }\end{array}$ & $\begin{array}{l}\text { Omeprazole (1), levofloxacin (7) and amoxicillin (8), or } \\
\text { omeprazole, amoxicillin, and rifabutin CBS+metronidazole }\end{array}$ \\
\hline 3. & Triple therapy & Bismuth+antibiotics+PPI, H2RA+2 antibiotics & $\begin{array}{l}\text { CBS+amoxicillin+omeprazole, } \\
\text { Ranitidine+metronidazole (3)+amoxycillin }\end{array}$ \\
\hline 4. & Quadruple therapy & PPI+Bismuth+two antibiotics & Omeprazole+CBS or BSS (12)+tetracycline (9)+ tinidazole (10) \\
\hline
\end{tabular}

Table 3: Enzymatic targets for organobismuth compounds

\begin{tabular}{|c|c|c|c|c|c|}
\hline S. No. & Enzyme & Enzyme activity & Inhibitory activity by bismuth drug & Type of inhibition & Reference \\
\hline 1. & Urease & $\begin{array}{l}\text { Neutralization of the gastric acid by } \\
\text { hydrolyzing urea to ammonia }\end{array}$ & $\begin{array}{l}\text { Blocking the substrates from reaching the } \\
\text { active site by binding to cysteine (Cys319) } \\
\text { residue at the active site }\end{array}$ & $\begin{array}{l}\text { Competitive } \\
\text { non-competitive }\end{array}$ & {$[63,64]$} \\
\hline 2. & $\begin{array}{l}\text { Alcohol } \\
\text { dehydrogenase }\end{array}$ & $\begin{array}{l}\text { Catalyzes reversible oxidation of } \\
\text { alcohol to acetaldehyde which } \\
\text { arbitrates mucosal damage }\end{array}$ & $\begin{array}{l}\text { Change in enzyme native structures by } \\
\text { binding to a cysteine residue of Baker's } \\
\text { yeast, interrupt the zinc site }\end{array}$ & non-competitive & {$[65]$} \\
\hline 3. & $\begin{array}{l}\text { Fumarate } \\
\text { reductase }\end{array}$ & $\begin{array}{l}\text { Essential for H. pylori colonization } \\
\text { unidirectional conversion of fumarate } \\
\text { to succinate }\end{array}$ & $\begin{array}{l}\text { Binding of bismuth to the enzyme can } \\
\text { inhibit the colonization of } H \text {. pylori }\end{array}$ & & \\
\hline 4. & Fumarase & $\begin{array}{l}\text { Conversion of fumarate to malic acid } \\
\text { for cellular energetics and production } \\
\text { of ATP }\end{array}$ & $\begin{array}{l}\text { Modification in bacterial flagellar rotation, } \\
\text { disarrange } \\
\text { bacterial energetics, obstruct the oxidative } \\
\text { ATP composition }\end{array}$ & non-competitive & {$[66]$} \\
\hline 5. & Proteases & $\begin{array}{l}\text { Glycoprotein constituents of mucin } \\
\text { are disgrace by phospholipase }\end{array}$ & $\begin{array}{l}\text { Bismuth binds to the calcium site of } \\
\text { phospholipases }\end{array}$ & & {$[61]$} \\
\hline
\end{tabular}

ATP: Adenosine triphosphate 


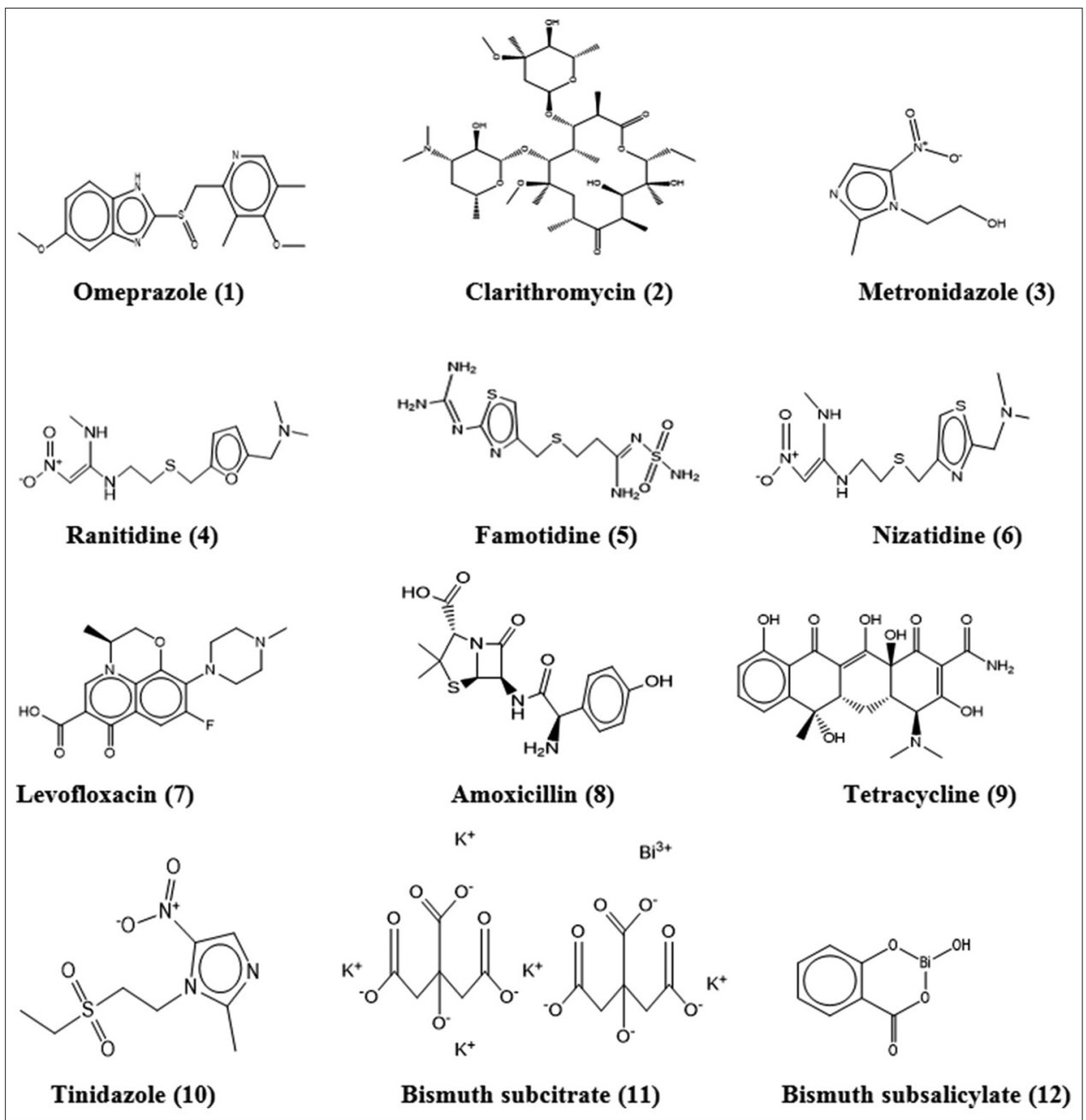

Fig. 2: Reported structures of drugs in Helicobacter pylori eradication

$\mathrm{Al}$ (III) and helps them to enter in human blood. Both N- and C-lobe iron-binding sites of human serum transferrin and recombinant N-lobe transferrin are vigorously binds to bismuth [73]. Similar to iron bismuth binds to transferrin along with carbonate as a synergistic anion, predicted by 13C-NMR. Even after extensive dialysis, removal of bismuth from transferrin complex cannot take place.

\section{NEWER ORGANOBISMUTH COMPOUNDS AGAINST H. PYLORI}

Diemer et al. synthesize and report single-crystal structures of novel complexes of bismuth with thiosemicarbazones and dithiocarbazonic acid methyl ester derivatives as a ligand which are also active against $H$. pylori [74]. Thiosemicarbazones were chosen for complex formation with bismuth due to their potential antibacterial and antiviral activity against influenza viruses, against protozoa, and Plasmodium berghei in mice and also against some types of tumor [75-78]. Complexes of thiosemicarbazones with different metal such as nickel, copper, iron, and cobalt were also reported as active to produce different biological activity. At low concentrations, all the novel complexes of bismuth with thiosemicarbazones and dithiocarbazonic acid methyl ester derivatives can actively inhibit the bacterium causing peptic ulcer.

Dittes report some new bismuth (III) and bismuth (V) tropolanato complexes along with thiosemicarbazones and dithiocarbazonic acid methyl ester derivatives in a review. Fig.3 details about the structures reported. An agar dilution test method is used to test activity against $H$. pylori for both types of complexes, the standards taken were bismuth citrate, bismuth salicylate, and bismuth nitrate aluminate and it was reported that thiosemicarbazones complexes were more active than the tropolonato complexes [79].

The interest toward the synthesis of new bismuth complexes extended and demand of therapeutically more efficacious bismuth compounds for some supplementary eradicate $H$. pylori leads to the synthesis of novel Bi (III) complexes of fluoroquinolones (norfloxacin, ofloxacin, ciprofloxacin, sparfloxacin, lomefloxacin, pefloxacin, and gatifloxacin) by Shaikh et al. [80]. Fluoroquinolones were chosen for the complex formation because they are already known broad-spectrum antibiotics [81] and the complex formed is an uncharged molecule so it is absorbed well and its bioavailability is also high. An agar diffusion method is used for the determination of activity against $H$. pylori and all complexes were found to be active with minimum inhibitory concentration (MIC) values of $1-4 \mathrm{mg} / \mathrm{L}(1-4 \mu \mathrm{g} / \mathrm{mL})$.

Bismuth complex of sulfosalicylate prepared and recrystallized from water - $[\mathrm{PhBi}(\mathrm{HSsal}) \mathrm{H} 2 \mathrm{O}],[\mathrm{PhBi}(\mathrm{HSsal}) \mathrm{EtOH}]$, and $\left\{\left[\mathrm{Bi}(\mathrm{HSsal})\left(\mathrm{H}_{2} \mathrm{Ssal}\right)\right.\right.$ $\left.\left.\left(\mathrm{H}_{2} \mathrm{O}\right)_{3}\right]_{2} \cdot 2 \mathrm{H}_{2} \mathrm{O}\right\}$ was synthesized in the same year by Andrews et al. Single crystal X-ray diffraction helps to reveal that the three complexes were polymeric in nature. The compounds were tested for the activity against H. pylori; it was reported that all three complexes show notable activity against the bacterium $H$. pylori of $<6.25 \mathrm{mg} / \mathrm{ml}$ [82]. Andrews also provide invaluable insight in this regard and propose and synthesize various novel complexes of bismuth with NSAIDs having general formula [BiL3]n or [BiL3·(H2O)]n where L is an NSAID [83]. They previously develop and establish methods for the successful formation of bismuth carboxylates [84], and bismuth salicylates [85] 
and NSAIDs are also salicylates and carboxylates, so these were used to synthesize the complex. The synthetic scheme adopted was:

$$
\mathrm{BiPh}_{3}+3 \mathrm{LH}\left[\mathrm{Bi}(\mathrm{L})_{3}\right]_{\mathrm{n}}+3 \mathrm{PhH}
$$

Reaction can be done in the presence of a solvent (Toluene, Reflux for $10-12 \mathrm{~h}$ ) or the absence of solvent $\left(1200^{\circ} \mathrm{C}\right.$ for $\left.4 \mathrm{~h}\right)$ and $\mathrm{L}$ is the different NSAIDs used such as ketoprofen, naproxen, ibuprofen, mefenamic acid, diflunisal, 5-chlorosalicylic acid, fenbufen, sulindac, tolfenamic acid, and flufenamic acid. Here also an agar dilution method was used to analyze the activity against $H$. pylori. All ten complexes show excellent in vitro activity with MIC values of $\geq 6.25 \mathrm{mg} / \mathrm{mL}$. Andrews also concentrated in the development of another complex of bismuth which exhibited remarkable anti-H. pylori activity with saccharinate and thiosaccarinate reported structures are given in Fig. 4 [86]. Five new complexes were synthesized [Ph2Bi(sac)] $\infty,\left[\mathrm{Bi}(\mathrm{sac})_{3}\right] \mathrm{n},\left[\mathrm{Ph}_{2} \mathrm{Bi}(\mathrm{tsac})\right] \infty,\left[\mathrm{PhBi}(\mathrm{tsac})_{2}\right] \mathrm{n}$, and $\left[\mathrm{Bi}(\mathrm{tsac})_{3}\right] \mathrm{n}$. Metal complexes of Saccharinates were also reported earlier with metals such as zinc, copper, and cobalt; they give inhibitory effect on carbonic anhydrase $[87,88]$. Due to its chelation properties, it is used as an antidote for metal poisoning. The complexes were characterized by NMR, IR, and single- crystal X-ray diffraction and were tested against three strains of $H$. pylori B128, 251, and 26695. Agar dilution method was used to set the MIC values which was $6.25 \mu \mathrm{g} /$ $\mathrm{mL}$ for saccharin complex $\left[\mathrm{Ph}_{2} \mathrm{Bi}(\mathrm{sac})\right] \infty$, [Bi(sac) $\left.{ }_{3}\right] \mathrm{n}$ and $50 \mu \mathrm{g} / \mathrm{mL}$ for $\left[\mathrm{Ph}_{2} \mathrm{Bi}-(\mathrm{tsac})\right] \infty, 12.5 \mu \mathrm{g} / \mathrm{mL}$ for $\left[\mathrm{PhBi}(\mathrm{tsac})_{2}\right] \mathrm{n}$, and $6.25 \mu \mathrm{g} / \mathrm{mL}$ for $\left[\mathrm{Bi}(\text { tsac })_{3}\right] \mathrm{n}$.

A range of bismuth (III) carboxylates were synthesized through salt metathesis using $\left[\mathrm{BiPh}_{3}\right]$ and $\mathrm{Ag}(\mathrm{I})$, thallium(I) carboxylates. However, thallium is toxic and silver is expensive so they were replaced by $\mathrm{Na}$ and $\mathrm{K}$ [89] and the above methods were used to synthesize the bismuth (III) aminoarene sulfonate complexes with careful control of temperature and reaction conditions by Andrews et al. Aminoarenesulfonates were chosen due to their biological activities such as esterase and chymotrypsin-inhibitory, and hypolipidemic effect [90-92]. Numerous structural variations are available and their electronic property as well as structures are similar to amino acids. The position of the amino group on arene $(-0,-p,-m)$, heterocyclic amines, monoprotic, and zwitterionic acids, and the ring size is varied from phenyl to naphthyl to choose the aminoarenesulfonates for complex development with bismuth. The yield of the synthesized complexes was compared and it was found that $\left[\mathrm{Bi}(\mathrm{OtBu})_{3}\right]$ at a low temperature produces a high yield for homoleptic tris (aminoarenesulfonato) bismuth (III) complexes. However, heteroleptic bismuth (III) complexes are only accessible here through the use of the Ag (I) complexes in reaction with $\left[\mathrm{Bi}(\mathrm{Ph})_{3-n}(\mathrm{Cl}) \mathrm{n}\right](\mathrm{n}=1$ or 2$)$. All complexes were powerful antimicrobials; active against $H$. pylori having MIC values ranged from $0.049 \mu \mathrm{g} / \mathrm{mL}$ to $12.5 \mu \mathrm{g} / \mathrm{mL}$. The same group of scientist also proposes some newer bismuth (III) complexes derived from $\alpha$ amino acids. They describe various synthetic approaches using $\left[\mathrm{BiPh}_{3}\right]$ [93] under both solvent-free and solvent-mediated methods; metathesis with Ag (I) [94] salts of the $\alpha$-amino acids and with $\left[\mathrm{Bi}(\mathrm{OtBu})_{3}\right]$ to synthesize tris-substituted bismuth (III) complexes using different polar and non-polar amino-acids such as L-phenylalanine, L-proline, L-methionine, L-cysteine, D,L-serine, L-tyrosine, L-aspartic acid, and L-glutamic acid [95] the first two methods were not feasible to synthesize the carboxylate complexes but the third method is superior using $\left[\mathrm{Bi}(\mathrm{OtBu})_{3}\right]$ at low temperature. The amino acids were chosen for the formation of complexes because it was demonstrated earlier through different studies that bismuth acts in vivo on proteins and peptides containing sulfur in the form of thiolates [96] such as cysteine and methionine including lactoferrin and transferrin [97-99]. The reaction scheme using $\left[\mathrm{Bi}(\mathrm{OtBu})_{3}\right]$ was:

$$
3 \mathrm{LH}_{\mathrm{n}}+\mathrm{m}\left[\mathrm{Bi}\left(\mathrm{O}^{\mathrm{t} B u}\right)_{3}\right]\left[\mathrm{Bi}_{\mathrm{m}} \mathrm{L}_{3}\right]
$$

The reaction is performed in the presence of THF, $\mathrm{N}_{2}$ at temperature $-780^{\circ} \mathrm{C}--400^{\circ} \mathrm{C}$ in Step 1 and $-400 \mathrm{C}$ to RT in Step 2 . For $n=1, m=1$ and For $n=2, m=2$. Synthesized compounds were quick to respond to temperature and moisture and were characterized through elemental analysis, NMR, ATR-IR, and electrospray ionization mass spectrometry. The complexes were also tested for their reliability to active against H. pylori; MIC values ranged from $0.049 \mu \mathrm{g} / \mathrm{mL}$ to $50 \mu \mathrm{g} / \mathrm{mL}$. The general progression allowed to manifest that bismuth (III) complexes of polar, neutral and aliphatic $\alpha$-amino acids gave lower MIC values compared to the bismuth (III) complexes of non-polar, acidic, and aromatic $\alpha$-amino acids.

In eager for searching more antibiotics for H. pylori eradication Andrews et al. also propose to synthesize bismuth (III) $\beta$-thioxoketonates. Nine different $\beta$-thioxoketonates of general formula $\mathrm{R} 1 \mathrm{C}(=0) \mathrm{CH}_{2} \mathrm{C}(=\mathrm{S}) \mathrm{R} 2$ (R1 and R2 $=\mathrm{C}_{6} \mathrm{H}_{5} ; \mathrm{R} 1=\mathrm{C}_{6} \mathrm{H}_{5}, \mathrm{R} 2=\mathrm{p}-\mathrm{CF}_{3} \mathrm{C}_{6} \mathrm{H}_{4} ; \mathrm{R} 1=\mathrm{p}-\mathrm{MeOC}_{6} \mathrm{H}_{4}, \mathrm{R} 2=\mathrm{C}_{6} \mathrm{H}_{5}$; $\mathrm{R} 1=\mathrm{p}-\mathrm{MeOC}_{6} \mathrm{H}_{4}, \quad \mathrm{R} 2=\mathrm{p}-\mathrm{CF}_{3} \mathrm{C}_{6} \mathrm{H}_{4} ; \quad \mathrm{R} 1=\mathrm{C}_{5} \mathrm{H}_{4} \mathrm{~N}, \quad \mathrm{R} 2=\mathrm{C}_{6} \mathrm{H}_{5} ; \quad \mathrm{R} 1=\mathrm{p}-\mathrm{IC}_{6} \mathrm{H}_{4}$, $\mathrm{R} 2=\mathrm{C}_{6} \mathrm{H}_{5} ; \mathrm{R} 1=\mathrm{C}_{6} \mathrm{H}_{5}, \mathrm{R} 2=\mathrm{p}-\mathrm{IC}_{6} \mathrm{H}_{4} ; \mathrm{R} 1=\mathrm{C}_{6} \mathrm{H}_{5}, \mathrm{R} 2=\mathrm{C}_{10} \mathrm{H}_{7}$, and R1 $=\mathrm{CH}_{3}, \mathrm{R} 2=\mathrm{C}_{6} \mathrm{H}_{5}$ and their tris-substituted bismuth (III) complexes were synthesized and well characterized by IR, NMR, and X-ray crystallography. All the bismuth (III) complexes were highly diligent against $H$. pylori with MIC values $\geq 3.125 \mu \mathrm{g} / \mathrm{mL}$. The bismuth (III) $\beta$-thioxoketonates complexes were also tested for anti-leishmanial activity, but the only compound $\left[\mathrm{Bi}\left\{\mathrm{C}_{5} \mathrm{H}_{4} \mathrm{NC}(=0) \mathrm{CHC}(=\mathrm{S}) \mathrm{C}_{6} \mathrm{H}_{5}\right\} 3\right]$ showed the highest activity [100].

Interest toward the synthesis of complexes was increases and Andrews et al. recently synthesize the bismuth complex with hydroxamic acid. According to them, these were better candidates for complex build out because they also play a role in the inhibition of urease enzyme. Targeting bismuth

hydroxamates provide prospective to develop new antibacterial compounds and provide a plan of action using siderophores as "trojan horses" for the uptake of bismuth into the microorganism. H. pylori utilizes host transferrin, lactoferrin, and heme for iron uptake, so they provide a strong bactericidal effect of bismuth (III) benzohydroxamates against the microorganism. Due to this, iron mimicking processes the complexes are highly effective to more strongly kill the bacteria. Four complexes $\left[\mathrm{Bi}_{2}(\mathrm{BHA})_{3}\right], \quad\left[\mathrm{Bi}(\mathrm{H}-\mathrm{BHA})_{3}\right], \quad[\mathrm{Bi}(\mathrm{BHA})-(\mathrm{H}-\mathrm{BHA})]$, and $\left[\mathrm{Bi}_{34} \mathrm{O}_{22}(\mathrm{BHA})_{22}(\mathrm{H}-\mathrm{BHA})_{14}(\mathrm{DMSO})_{6}\right]$ were formed where BHA is benzohydroxamic acid structures were shown in Fig. 5 [101]. The bactericidal activity against three strains of $H$. pylori B128, 251, and 26695 was tested by agar diffusion method, and MIC value ranges from 0.05 to $6.25 \mathrm{mg} / \mathrm{mL}$. They also reported that benzohydroxamates were potentially more effective than the other complexes studied until now. Hence, further investigation of these complexes is required, and in same context novel bismuth (III) hydroxamates derived from N-methylfurohydroxamic acid (H-MFHA), N-benzoyl-Nphenylhydroxamic acid (H-BPHA), salicylhydroxamic acid (H2-SHA), and acetohydroxamic acid (H2-AHA) were also synthesized [102]. Only acetohydroxamic acid is showed agility at low concentrations having MIC $6.25 \mu \mathrm{g} / \mathrm{mL} ; 83.26 \mu \mathrm{M}$.

$$
\begin{gathered}
\mathrm{R}=\mathrm{O}-(\mathrm{OH}) \mathrm{C}_{6} \mathrm{H}_{5} \mathrm{R}=\mathrm{O}-(\mathrm{OH}) \mathrm{C}_{6} \mathrm{H}_{5} \mathrm{R}=\mathrm{O}-(\mathrm{OH}) \mathrm{C}_{6} \mathrm{H}_{5} \\
\mathrm{R}=\mathrm{C}_{6} \mathrm{H}_{5} \mathrm{R}=\mathrm{C}_{6} \mathrm{H}_{5} \mathrm{R}=\mathrm{C}_{6} \mathrm{H}_{5}
\end{gathered}
$$

\section{ORGANOBISMUTH COMPOUNDS WITH GASTROCYTOPROTECTIVE ACTIVITY}

Andre Robert in 1979 was first to introduce the term "cytoprotection," in a comprehensive sense it is related to protection against gastric mucosal injury by a mechanism other than reluctance or acclimatization of gastric acid. However, the surface cells are often not protected by these agents, so the term gastroprotection is suggested by Szabo and Szelenyi. Bismuth compounds are used as gastroprotective due to their local defensive, emollient, and antacid properties. Colloidal bismuth salt forms a protective coating against acid, pepsin, and bile by chelating proteins in the ulcer crater. A variety of experimental gastric mucosal lesions in the rat has been shown too prevented by this salt. Its cytoprotective effect has been attributed by increased luminal availability of epidermal growth factor, stimulation of prostaglandins, and stimulation of phospholipid-rich mucus [103]. 


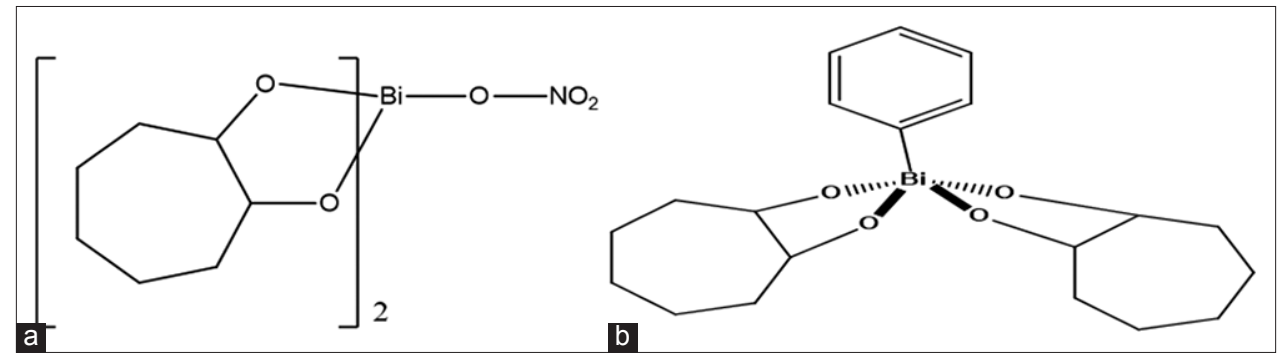

Fig. 3: Structure of bismuth tropolanato complexes, (a) in +3 and (b) in +5 oxidation state

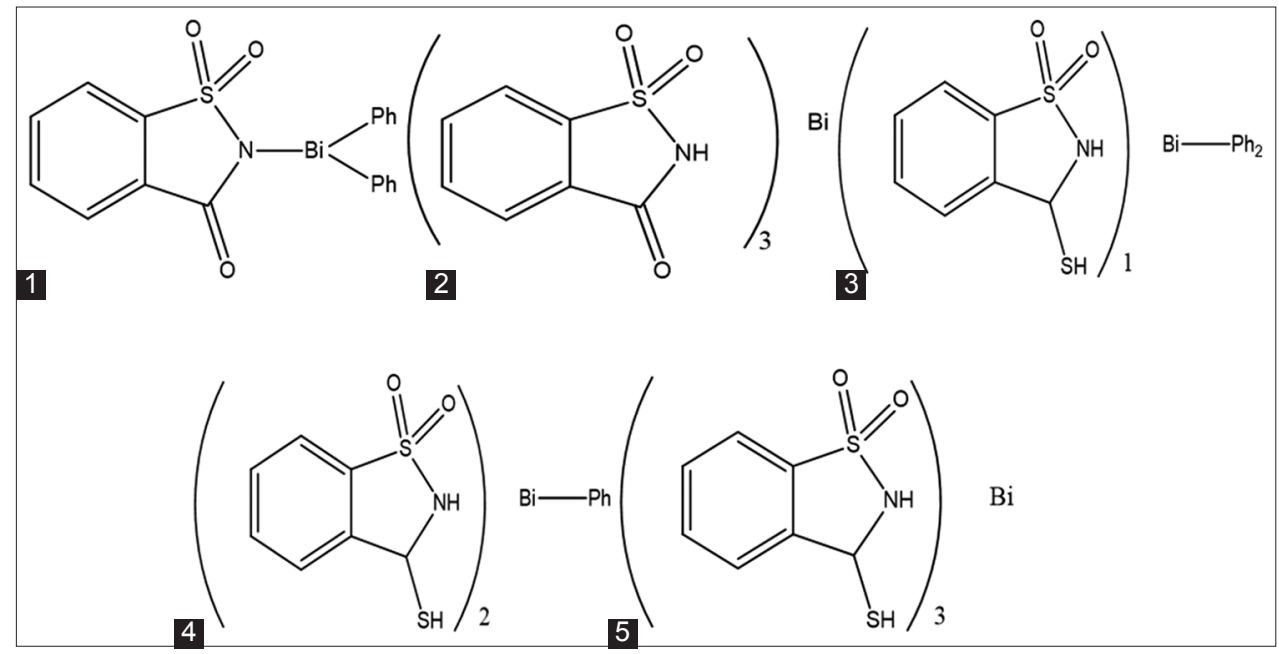

Fig. 4: Structure of bismuth complexes $1,2,3$ with saccharinate and 4,5 with thiosaccarinate

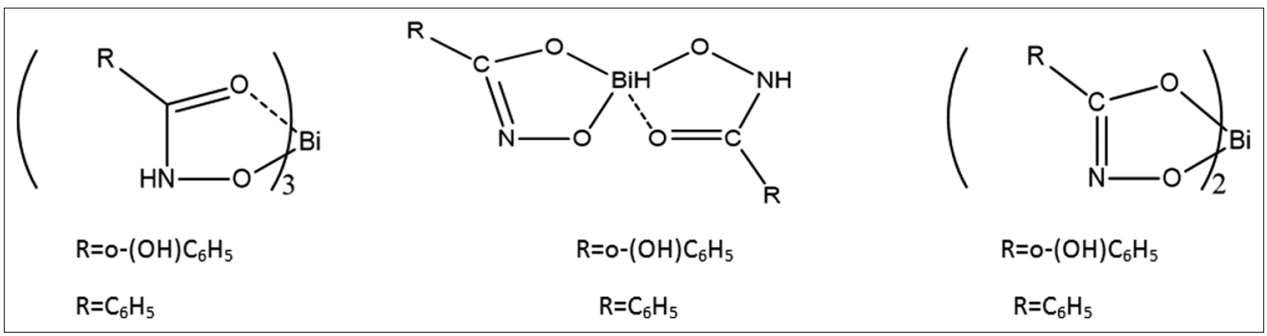

Fig. 5: Structure of bismuth complexes with hydroxamates

Complex bismuth salt of citric acid is known as CBS. It is responsible for the appearance of bismuth oxychloride (BiOCl) and citric acid in the body, BiOCl is below par soluble, but bismuth ions have import physiological effects. It not only provides gastroprotective action but can also decrease the relapse rate. Prostaglandins also provide both antiulcer and ulcer protective activity and sucralfate is a standard drug used for experimental purposes. An acute gastric lesion induced by acidified aspirin and absolute ethanol in rats model was used to compare the effect of CBS with sucralfate and prostaglandins by Konturek et al. They found through a study that colloidal bismuth subcitrate is more potent than sucralfate and antiulcer action is dose-dependent. This study also shows that colloidal bismuth subcitrate is remarkable for the protection of gastric mucosa against acute necrosis induced by ethanol. CBS increase the biosynthesis of prostaglandins which stimulate the mucus alkaline secretion, tightening the mucosal barrier, increase in the mucosal refusal to accept acid, and mucosal cell renovation [104].

Tytgat reports a review on CBS allocating about the mechanism of action and its efficacy on DU and GU. He discussed that the defensive action of CBS is due to its plating film on the ulcer base, bolster of the mucus barriers against further acid attacks of the mucosa and stimulation of biosynthesis of endogenous prostaglandins with bicarbonate secretions. All these factors can speed up the ulcer healing and retard the relapses in both of the cases. He reports this remarkable phenomenon in ten different trails explaining two reasons that either CBS helps in eradication of $H$. pylori and results in improvements in gastroduodenal histology or stimulation of biosynthesis of endogenous prostaglandins may results in these relapses; further, he emphasizes that the reason first is more responsible for lower relapses [105]. Pharmacokinetic and pharmacodynamics studies of CBS were done by Wagstaff et al. A very low level of it is absorbed through GIT, most of the absorbed bismuth is found in kidney and some traces in the brain and it is excreted through urine and in some amount in feces. Healing of peptic ulcers in patients occurs over 4-8 weeks of treatment. After healing with CBS, the epithelial microvilli in the peptic ulcer scar are closer to normal like those in patients treated with cimetidine [106].

An indomethacin-induced injury in rats was used by Tanaka et al. to report the cytoprotective effect of BSS. An in vivo microscopic technique was used in which acid output, surface cell intracellular $\mathrm{pH}$, gastric mucus gel thickness, and mucosal blood flow were measured simultaneously and using this technique they report that BSS improves $\mathrm{pH}$ during acid super fusion without affecting gel thickness, they cannot affect either mucosal blood flow or acid output [107]. BSS is a trivalent 
salt of bismuth and salicylic acid, it reacts with hydrochloric acid in the stomach to form $\mathrm{BiOCl}$ and salicylic acid, it is also an insoluble salt so some amount is absorbed but remaining amount pass as such in duodenum and here reacts with bicarbonates and phosphates to form bismuth subcarbonate and bismuth phosphate, which results in darkening of stool. No other major side effects were noted except this darkening of the stool using BSS [108]. Tay et al. report that BSS can reduce peptic injury of the esophagus in rabbits. In this, in vivo study, they select perfused rabbit model to check the prevention of mucosal injury caused by pepsin through BSS and report a remarkable reduction in the pepsin induced interference of the mucosal barrier, as well as the difference in morphology by obstructing the proteolytic action of pepsin by BSS [109].

Stables et al. report $\mathrm{RBC}$, which is a complex salt of ranitidine and bismuth citrate, various other salts were designed, but this one is stable enough. They report that along with the gastric acid anti-secretory effect of ranitidine these salts were protective against ethanol-induced gastric mucosal damage, inhibit pepsin activity, and suppress the activity of $H$. pylori and the related bacterium. Using the indomethacininduced antral damage model, they report that RBC is most potent in providing protective effects among RBC, bismuth citrate, ranitidine hydrochloride, and tripotassium dicitrato bismuthate.

Kotzampassi et al. reported RBC-related expansion of gastric mucosal microcirculation and stalwart mucus gel thickness which may contribute to the precautionary action; the examination was performed in fasted rats to assess the gastroprotective potential of ranitidine bismuth citrate. They report that there is an increase in blood flow of gastric mucosa as well as a significant improvement in gastric mucosal perfusion just an hour after a single oral dose of $25 \mathrm{mg} / \mathrm{Kg}$ body weight of RBC. Blood flow plays a very crucial role in the maintenance of gastric mucosal probity, since it regulates the transport of oxygen and nutritional substances and the fast removal of toxic metabolites and back-diffused hydrogen ions and other irritants [110].

\section{FUTURE PERSPECTIVE}

Various bismuth complexes such as CBS, BSS, RBC, and other novel bismuth complexes with amino-acids, aminoarenesulfonates, fluoroquinolones, sulfosalicylates, saccharinates, tropolanato, NSAIDs, thioxoketonates, benzohydroxamates, and thiosemicarbazones are mentioned above in the review which helps in the eradication of H. pylori as well as provide cytoprotective action through diverse mechanisms. These include disruption of multiple biological pathways through binding to various enzymes such as urease, ADH, fumarate reductase, fumarase, and protease and by binding to other intracellular proteins of $H$. pylori like heat shock protein-A and disruptions of nickel and iron homeostasis. Bismuth action is also exerted through binding to proteins such as metallothionein, transferrin, and lactoferrin.

The growing incidence of antimicrobial resistance has warned pharmaceutical scientists to implement new approaches for eradicating $H$. pylori infection. The therapeutic achievements of established drugs have been declined to significant levels. This emphasizes to explore some more potent bismuth complexes which specifically target some enzymatic actions or physiological processes in the organism which directly helps in the destruction of the bacterium.

H. pylori treatment may enter into an entirely new resistance era in the coming future which accounts for the development of some novel enzyme targeted approaches. In the current generation's bismuth containing triple or quadruple therapy is an alternative line of treatment for $H$. pylori infection which was well established against multiple targets as mentioned above. Recently, some novel targets have been identified that warrants further investigation of bismuthcontaining compounds. Arginase has been established as one of the potential targets for a variety of synthesized derivatives and natural compounds. Arginase is a binuclear manganese metalloenzyme that converts L-arginine into ornithine and urea and it is also necessary for the growth of the infectious pathogen like H. pylori and suspected to be a cause of gastritis and peptic ulcers. It was reported by Pudlo et al. that alpha amino-acids such as glycine, alanine, valine, leucine, and isoleucine are weak inhibitors of arginase. Ornithine, lysine, L-cysteine, and L-glutamic acid are also inhibitors of arginase [111]. Amino acid derivatives such as hydroxyl derivative of L-arginine and alpha-difluromethylornithine an ornithine derivative are also reported as inhibitors of arginase. In silico approaches to identify the plausible binding sites of arginase followed by rational drug designing strategies to construct novel alpha amino-acid complexes of bismuth may be tested to explore the arginase mediated mechanism to target H. pylori.

Investigations on bacterial physiology on molecular levels lead to the discovery of some new mechanistic approaches like inhibition of shikimate pathway which is responsible for the production of some vital amino acids. Several enzymes involved at different levels of shikimate pathway have been investigated and subsequently targeted. Some other crucial targets have been identified by computational approaches which include the discovery of the succinylase pathway which was utilized by H. pylori to produce lysine [112]. Exploration of these pathways with bismuth containing compounds may provide a valuable understanding of novel mechanisms in the treatment of peptic ulcers.

\section{ACKNOWLEDGMENT}

The authors are thankful to the Faculty of Pharmacy, Integral University for providing all the necessary facilities related to the present work (Manuscript Communication Number: IU/R\&D/2018-MCN000511) along with Hygia Institute of Pharmacy, Lucknow, for providing the valuable support for the research work.

\section{CONFLICTS OF INTEREST}

There are no conflicts of interest.

\section{REFERENCES}

1. Freston JW. The pathophysiological and pharmacological basis of peptic ulcer therapy. Toxicol Pathol 1988;16:260-6.

2. Kaur A, Singh R, Sharma R, Kumar S. Peptic ulcer: A review on etiology and pathogenesis. Int Res J Pharm 2012;3:34-3.

3. Zatorski H. Introduction to Gastrointestinal Diseases. Vol. 2. Switzerland: Springer; 2017. p. 7-20.

4. Rodríguez LA, Tolosa LB. Risk of upper gastrointestinal complications among users of traditional NSAIDs and COXIBs in the general population. Gastroenterology 2007;132:498-506

5. Gabriel SE, Jaakkimainen L, Bombardier C. Risk for serious gastrointestinal complications related to use of nonsteroidal anti-inflammatory drugs. A meta-analysis. Ann Intern Med 1991;115:787-96.

6. Scharschmidt BF. Peptic ulcer disease. Pathophysiology and current medical management. West J Med 1987;146:724-33.

7. Mertz HR, Walsh JH. Peptic ulcer pathophysiology. Med Clin North Am 1991;75:799-814.

8. Rosenstock S, Jørgensen T, Bonnevie O, Andersen L. Risk factors for peptic ulcer disease: A population based prospective cohort study comprising 2416 Danish adults. Gut 2003;52:186-93.

9. Chou SP. An examination of the alcohol consumption and peptic ulcer association results of a national survey. Alcohol Clin Exp Res 1994; 18:149-53.

10. Ashley MJ. Smoking and diseases of the gastrointestinal system: An epidemiological review with special reference to sex differences. Can J Gastroenterol 1997;11:345-52.Ashley MJ.

11. Monson RR. Cigarette smoking and body form in peptic ulcer. Gastroenterology 1970;58:337-44

12. Peters MN, Richardson CT. Stressful life events, acid hypersecretion, and ulcer disease. Gastroenterology 1983;84:114-9.

13. Medalie JH, Stange KC, Zyzanski SJ, Goldbourt U. The importance of biopsychosocial factors in the development of duodenal ulcer in a cohort of middle-aged men. Am J Epidemiol 1992;136:1280-7.

14. Ray WA, Chung CP, Stein CM, Smalley WE, Hall K, Arbogast PG, et al. Risk of peptic ulcer hospitalizations in users of NSAIDs with gastroprotective cotherapy versus coxibs. Gastroenterology 2007; 133:790-8. 
15. Goh KL. Helicobacter pylori and peptic ulcer disease a causal link. Med J Malaysia 1997;52:161-8.

16. de Martel C, Parsonnet J. Helicobacter pylori infection and gender: A meta-analysis of population-based prevalence surveys. Dig Dis Sci 2006;51:2292-301.

17. Granström M, Tindberg Y, Blennow M. Seroepidemiology of helicobacter pylori infection in a cohort of children monitored from 6 months to 11 years of age. J Clin Microbiol 1997;35:468-70.

18. Das J, Nazir MF. Helicobacter pylori infection in children; diagnosis and treatment a review. Bangladesh J Child Health 2005;29:22-30.

19. O'Connor HJ. The role of Helicobacter pylori in peptic ulcer disease. Scand J Gastroenterol Suppl 1994;201:11-5.

20. Joshi YK. Helicobacter pylori infection: Current status. J Indian Acad Clin Med 2000;5:148-55.

21. McNulty CA, Dent JC, Uff JS, Gear MW, Wilkinson SP. Detection of Campylobacter pylori by the biopsy urease test: An assessment in 1445 patients. Gut 1989;30:1058-62.

22. Goodwin CS, Blincow ED, Warren JR, Waters TE, Sanderson CR, Easton L, et al. Evaluation of cultural techniques for isolating Campylobacter pyloridis from endoscopic biopsies of gastric mucosa. J Clin Pathol 1985;38:1127-31.

23. Jones DM, Lessells AM, Eldridge J. Campylobacter like organisms on the gastric mucosa: Culture, histological, and serological studies. J Clin Pathol 1984;37:1002-6.

24. Moter A, Göbel UB. Fluorescence in situ hybridization (FISH) for direct visualization of microorganisms. J Microbiol Methods 2000;41:85-112.

25. Shahamat M, Alavi M, Watts JE, Gonzalez JM, Sowers KR, Maeder DW, et al. Development of two PCR-based techniques for detecting helical and coccoid forms of Helicobacter pylori. J Clin Microbiol 2004;42:3613-9.

26. Gulcan EM, Varol A, Kutlu T, Cullu F, Erkan T, Adal E, et al. Helicobacter pylori stool antigen test. Indian J Pediatr 2005;72:675-8.

27. Rathbone BJ, Wyatt JI, Worsley BW, Shires SE, Trejdosiewicz LK, Heatley RV, et al. Systemic and local antibody responses to gastric Campylobacter pyloridis in non-ulcer dyspepsia. Gut 1986;27:642-7.

28. Graham DY, Klein PD, Evans DJ Jr., Evans DG, Alpert LC, Opekun AR, et al. Campylobacter pylori detected noninvasively by the 13C-urea breath test. Lancet 1987;1:1174-7.

29. O'Brien B, Goeree R, Mohamed AH, Hunt R. Cost-effectiveness of Helicobacter pylori eradication for the long-term management of duodenal ulcer in Canada. Arch Intern Med 1995;155:1958-64.

30. Veldhuyzen van Zanten SJ, Sherman PM, Hunt RH. Helicobacter pylori: New developments and treatments. CMAJ 1997;156:1565-74.

31. Nakajima S, Graham DY, Hattori T, Bamba T. Strategy for treatment of Helicobacter pylori infection in adults. I. Updated indications for test and eradication therapy suggested in 2000. Curr Pharm Des 2000;6:1503-14.

32. Cassel-Beraud AM, Le Jan J, Mouden JC, Andriantsoa M, Andriantsiferana R. Preliminary study of the prevalence of Helicobacter pylori in Tananarive, Madagascar and the antibacterial activity in vitro of 13 Malagasy medicinal plants on this germ. Arch Inst Pasteur Madagascar 1991;59:9-23.

33. Chenoll E, Casinos B, Bataller E, Astals P, Echevarría J, Iglesias JR, et al. Novel probiotic Bifidobacterium bifidum CECT 7366 strain active against the pathogenic bacterium Helicobacter pylori. Appl Environ Microbiol 2011;77:1335-43

34. Chen L, Li Y, Li J, Xu X, Lai R, Zou Q, et al. An antimicrobial peptide with antimicrobial activity against Helicobacter pylori. Peptides 2007;28:1527-31

35. Lee JH, Shim JS, Lee JS, Kim JK, Yang IS, Chung MS, et al. Inhibition of pathogenic bacterial adhesion by acidic polysaccharide from green tea (Camellia sinensis). J Agric Food Chem 2006;54:8717-23.

36. Kabir S. The current status of Helicobacter pylori vaccines: A review. Helicobacter 2007; 12:89-102.

37. Malfertheiner P, Megraud F, O'Morain C, Bazzoli F, El-Omar E, Graham D, et al. Current concepts in the management of Helicobacter pylori infection: The Maastricht III consensus report. Gut 2007;56:772-81.

38. Fock KM, Katelaris P, Sugano K, Ang TL, Hunt R, Talley NJ, et al. Second Asia-Pacific consensus guidelines for Helicobacter pylori infection. J Gastroenterol Hepatol 2009;24:1587-600.

39. Lambert JR, Midolo P. The actions of bismuth in the treatment of Helicobacter pylori infection. Aliment Pharmacol Ther 1997; 11 Suppl 1:27-33.

40. Mégraud F. The challenge of Helicobacter pylori resistance to antibiotics: The comeback of bismuth-based quadruple therapy. Therap
Adv Gastroenterol 2012;5:103-9.

41. Konturek SJ, Radecki T, Piastucki I, Drozdowicz D. Studies on the gastroprotective and ulcer-healing effects of colloidal bismuth subcitrate. Digestion 1987;37 Suppl 2:8-15.

42. Tanaka S, Guth PH, Paulsen G, Kaunitz JD. Gastroprotective effect of ranitidine bismuth citrate is associated with increased mucus bismuth concentration in rats. Gut 1996;39:164-71.

43. Stables R, Campbell CJ, Clayton NM, Clitherow JW, Grinham CJ, McColm AA, et al. Gastric anti-secretory, mucosal protective, antipepsin and anti-helicobacter properties of ranitidine bismuth citrate. Aliment Pharmacol Ther 1993;7:237-46.

44. Konturek S, Brzozowski T, Drozdowicz D, Bielanski W. Campylobacter pylori. New York: Springer; 1988. p. 184-92.

45. Sun H, Szeto KY. Binding of bismuth to serum proteins: Implication for targets of bi (III) in blood plasma. J Inorg Biochem 2003;94:114-20.

46. Tooth B. The Hydrothermal Chemistry of Bismuth and the Liquid Bismuth Collector Model, Thesis. Adelaide: University Adelaide; 2013.

47. Silver AF, Ash AG, Stone AG, Strontium AG, Sulfur BG, Talc BG, et al. Mineral Commodity Summaries. United States: Geological Survey; 2011

48. Ojebuoboh FK. Bismuth Production, properties, and applications. JOM 1992;44:46-9.

49. Naumov AV. World market of bismuth: A review. Russ J Non Ferrous Metals 2007;48:10-6.

50. Habashi F. Encyclopedia of Metalloproteins New York: Springer; 2013. p. 283-4.

51. Cotton FA, Wilkinson G, Murillo CA, Bochmann M. Advanced Organic Chemistry. New York: John Wiley and Sons; 1999.

52. Busev AI, Tiptsova VG, Ivanov VM. Hand Book of the Analtical Chemistry of Rare Elements. Ann Arbor: Ann Arbor Hunphrey Science Publishers; 1970.

53. Ulvenlund S, Bengtsson LA. Univalent bismuth a subvalent main group metal ion stable in aqueous solution. Acta Chem Scan Col 1994;48:635-9.

54. Wang Y, Hu L, Xu F, Quan Q, Lai YT, Xia W, et al. Integrative approach for the analysis of the proteome-wide response to bismuth drugs in Helicobacter pylori. Chem Sci 2017;8:4626-33.

55. Slomiany BL, Kasinathan C, Slomiany A. Lipolytic activity of Campylobacter pylori: Effect of colloidal bismuth subcitrate (De-nol) Am J Gastroenterol 1989;84:1273-7.

56. Nilius M, Ströhle A, Bode G, Malfertheiner P. Coccoid like forms (CLF) of Helicobacter pylori. Enzyme activity and antigenicity. Zentralbl Bakteriol 1993;280:259-72.

57. Midolo PD, Norton A, Itzstein Von M, Lambert JR. Novel bismuth compounds have in vitro activity against Helicobacter pylori. FEMS Microbiol Lett 1997; 157:229-32.

58. Sox TE, Olson CA. Binding and killing of bacteria by bismuth subsalicylate. Antimicrob Agents Chemother 1989;33:2075-82

59. Armstrong JA, Wee SH, Goodwin CS, Wilson DH. Response of Campylobacter pyloridis to antibiotics, bismuth and an acidreducing agent in vitro an ultrastructural study. J Med Microbiol 1987;24:343-50.

60. Domenico P, Landolphi DR, Cunha BA. Reduction of capsular polysaccharide and potentiation of aminoglycoside inhibition in gramnegative bacteria by bismuth subsalicylate. J Antimicrob Chemother 1991;28:801-10

61. Lee SP. A potential mechanism of action of colloidal bismuth subcitrate: Diffusion barrier to hydrochloric acid. Scand J Gastroenterol Suppl 1982;80:17-21.

62. Konturek SJ, Radecki T, Piastucki I, Drozdowicz D. Advances in the understanding of the mechanism of cytoprotective action by colloidal bismuth subcitrate. Scand J Gastroenterol Suppl 1986;122:6-10.

63. Zhang L, Mulrooney SB, Leung AF, Zeng Y, Ko BB, Hausinger RP, et al. Inhibition of urease by bismuth(III): Implications for the mechanism of action of bismuth drugs. Biometals 2006;19:503-11.

64. Habala L, Devínsky F, Egger A. REVIEW: Metal complexes as urease inhibitors. J Coord Chem 2018;71:1-49.

65. Jin L, Szeto KY, Zhang L, Du W, Sun H. Inhibition of alcohol dehydrogenase by bismuth. J Inorg Biochem 2004;98:1331-7.

66. Chen Z, Zhou Q, Ge R. Inhibition of fumarase by bismuth(III): Implications for the tricarboxylic acid cycle as a potential target of bismuth drugs in Helicobacter pylori. Biometals 2012;25:95-102.

67. Cun $\mathrm{S}$, Li H, Ge R, Lin MC, Sun $\mathrm{H}$. A histidine-rich and cysteine-rich metal-binding domain at the $\mathrm{C}$ terminus of heat shock protein $\mathrm{A}$ from Helicobacter pylori: Implication for nickel homeostasis and bismuth susceptibility. J Biol Chem 2008;283:15142-51. 
68. He X, Liao X, Li H, Xia W, Sun H. Bismuth-induced inactivation of ferric uptake regulator from Helicobacter pylori. Inorg Chem 2017;56:15041-8.

69. Bland MV, Ismail S, Heinemann JA, Keenan JI. The action of bismuth against Helicobacter pylori mimics but is not caused by intracellular iron deprivation. Antimicrob Agents Chemother 2004;48:1983-8.

70. Lemire JA, Harrison JJ, Turner RJ. Antimicrobial activity of metals: Mechanisms, molecular targets and applications. Nat Rev Microbiol 2013;11:371-84.

71. Herrmann WA, Herdtweck E, Pajdla L. Metal complexes in biology and medicine, VI synthesis and structure of (Penicillaminato-O,S,N) bismuth(III) Chloride. Chem Ber 1993;126:895-8.

72. Shaw CF, Savas MM. In: Stillman MJ, Shaw CF, Suzuki KT, editors. Metallothioneins: Synthesis, Structure and Properties of Metallothioneins, Phytochelatins, and Metalthiolate Complexes. New York: VCH; 1992. p. 144-62.

73. Li H, Sadler PJ, Sun H. Rationalization of the strength of metal binding to human serum transferrin. Eur J Biochem 1996;242:387-93.

74. Diemer R, Dittes U, Nuber B, Seifried V, Opferkuch W, Keppler BK, et al. Synthesis, characterization and molecular structures of some bismuth(III) complexes with thiosemicarbazones and dithiocarbazonic acid methylester derivatives with activity against Helicobacter pylori. Met Based Drugs 1995;2:271-92.

75. Domagk G, Behnisch R, Mietzsch F, Schmidt H. Uber a new, against tubercle bacilli in vitro effective class of compounds. Natural Sciences 1946;33:315.

76. Easmon J, Heinisch G, Holzer W, Rosenwirth B. Pyridazines. 63. Novel thiosemicarbazones derived from formyl and acyldiazines: Synthesis, effects on cell proliferation, and synergism with antiviral agents. J Med Chem 1992;35:3288-96

77. Klayman DL, Scovill JP, Bartosevich JF, Bruce J 2-acetylpyridine thiosemicarbazones 5. 1-[1-(2-pyridyl)ethyl]-3-thiosemicarbazides as potential antimalarial agents. J Med Chem 1983;26:35-9.

78. Antonini I, Claudi F, Cristalli G, Franchetti P, Grifantini M, Martelli S, et al. Synthesis of 4-amino-1-beta-D-ribofuranosyl-1H-pyrrolo[2,3-b] pyridine (1-deazatubercidin) as a potential antitumor agent. J Med Chem 1982;25:1258-61.

79. Dittes U, Vogel E, Keppler BK. Overview on bismuth (III) and bismuth (V) tropolanato complexes with activity against $H$. pylori. Coord Chem Rev 1997; 163:345-64.

80. Shaikh AR, Giridhar R, Megraud F, Yadav MR. Metalloantibiotics: Synthesis, characterization and antimicrobial evaluation of bismuthfluoroquinolone complexes against Helicobacter pylori. Acta Pharm 2009;59:259-71.

81. Sharma PC, Jain A, Jain S. Fluoroquinolone antibacterials: A review on chemistry, microbiology and therapeutic prospects. Acta Pol Pharm 2009;66:587-604

82. Andrews PC, Deacon GB, Ferrero RL, Junk PC, Karrar A, Kumar I, et al. Bismuth(III) 5-sulfosalicylate complexes: Structure, solubility and activity against Helicobacter pylori. Dalton Trans 2009;32:6377-84.

83. Andrews PC, Ferrero RL, Junk PC, Kumar I, Luu Q, Nguyen K, et al. Bismuth(III) complexes derived from non-steroidal anti-inflammatory drugs and their activity against Helicobacter pylori. Dalton Trans 2010;39:2861-8.

84. Andrews PC, Deacon GB, Jackson WR, Maguire M, Scott NM, Skelton BW, et al. Solvent free synthesis of bismuth thiolates and carboxylates. J Chem Soc Dalton Trans 2002;24:4634-8.

85. Andrews PC, Deacon GB, Forsyth CM, Junk PC, Kumar I, Maguire M, et al. Towards a structural understanding of the anti-ulcer and antigastritis drug bismuth subsalicylate. Angew Chem Int Ed Engl 2006; $45: 5638-42$.

86. Andrews PC, Ferrero RL, Craig M, Forsyth CM, Junk PC, Jonathan G, et al. Bismuth(III) saccharinate and thiosaccharinate complexes and the effect of ligand substitution on their activity against Helicobacter pylori. Organometallics 2011;30:6283-91.

87. Raad AT, Boghaei DM, Khavasi HR. Saccharin complexes of zinc(II) with phenanthroline and 2,9-dimethyl-1,10-phenanthroline: Synthesis and characterization. J Coord Chem 2010;63:273-83

88. Frija LM, Alegria EC, Sutradhar M, Cristiano ML, Ismael A, Kopilovich M, et al. Copper(II) and cobalt(II) tetrazole-saccharinate complexes as effective catalysts for oxidation of secondary alcohols. J Mol Catal A 2016;425:283-90.

89. Ali M, McWhinnie WR. Organobismuth (III) and organobismuth (V) carboxylates and their evaluation as paint driers. Appl Organomet Chem 1993; 7:137-41

90. Ogawa K, Terada T, Muranaka Y, Hamakawa T, Fujii S. Studies on hypolipidemic agents. V. Synthesis and esterase-inhibitory activity of 2-(1, 4- and 4,4-dialkylcyclohexyl)-2-oxoethyl are nesulfonates. Chem Pharm Bull (Tokyo) 1987;35:4130-6.

91. Ogawa K, Terada T, Muranaka Y, Hamakawa T, Ohta S, Okamoto M, et al. Studies on hypolipidemic agents. IV. Syntheses and biological activities of trans and cis-2-(4-alkylcyclohexyl)-2-oxoethyl are nesulfonates. Chem Pharm Bull (Tokyo) 1987;35:3276-83.

92. Ogawa K, Terada T, Muranaka Y, Hamakawa T, Fujii S. Studies on hypolipidemic agents. III. Synthesis and esterase-inhibitory activity of omega-cycloalkyl-2-oxoalkyl are nesulfonates. Chem Pharm Bull (Tokyo) 1987;35:2426-36.

93. Suzuki H, Matano Y. Organobismuth Chemistry. New York: Elsevier; 2001. p. 159-61.

94. Garner CD, Hughes B. Inorganic compounds containing the trifluoroacetate group. IV. Preparation and properties of arsenic tris (trifluoroacetate), [As(O2CCF3)], and related compounds. Inorg Chem $1975 ; 14: 1722-4$

95. Busse M, Border E, Junk PC, Richard L, Ferrero RL, Andrews PC. Bismuth(III) complexes derived from $\alpha$-amino acids: The impact of hydrolysis and oxido-cluster formation on their activity against Helicobacter pylori. Dalton Trans 2014;43:17980-90.

96. Sadler PJ, Muncie C, Shipman MA. Biological Inorganic Chemistry Structure and Reactivity. California: University Science Books; 2007.

97. Sun H, Li H, Mason AB, Woodworth RC, Sadler PJ. Competitive binding of bismuth to transferrin and albumin in aqueous solution and in blood plasma. J Biol Chem 2001;276:8829-35.

98. Li H, Sun H. Recent advances in bioinorganic chemistry of bismuth. Curr Opin Chem Biol 2012;16:74-83.

99. Ge R, Chen Z, Zhou Q. The actions of bismuth in the treatment of Helicobacter pylori infections: An update. Metallomics 2012;4:239-43.

100. Andrews PC, Blair VL, Ferrero RL, Junk PC, Kedzierski L, Peiris RM, et al. Bismuth(III) $\beta$-thioxoketonates as antibiotics against Helicobacter pylori and as anti-leishmanial agents. Dalton Trans 2014;43:1279-91.

101. Pathak A, Blair VL, Ferrero RL, Mehring M, Andrews PC Bismuth(III) benzohydroxamates: Powerful anti-bacterial activity against Helicobacter pylori and hydrolysis to a unique bi34 oxidocluster [Bi34O22(BHA)22(H-BHA)14(DMSO)6]. Chem Commun (Camb) 2014;50:15232-4

102. Pathak A, Blair VL, Ferrero RL, Junk PC, Tabor RF, Andrews PC, et al. Synthesis and structural characterisation of bismuth(III) hydroxamates and their activity against Helicobacter pylori. Dalton Trans 2015;44:16903-13.

103. D’Souza RS, Dhume VG. Gastric cytoprotection. Indian J Physiol Pharmacol 1991;35:88-98.

104. Konturek SJ, Radecki T, Piastucki I, Brzozowski T, Drozdowicz D. Gastrocytoprotection by colloidal bismuth subcitrate (De-nol) and sucralfate. Role of endogenous prostaglandins. Gut 1987;28:201-5.

105. Tytgat GN. Colloidal bismuth subcitrate in peptic ulcer a review. Digestion 1987;37 Suppl 2:31-41.

106. Wagstaff AJ, Benfield P, Monk JP. Colloidal bismuth subcitrate. A review of its pharmacodynamic and pharmacokinetic properties, and its therapeutic use in peptic ulcer disease. Drugs 1988;36:132-57.

107. Tanaka S, Guth PH, Carryl OR, Kaunitz JD. Cytoprotective effect of bismuth subsalicylate in indomethacin-treated rats is associated with enhanced mucus bismuth concentration. Aliment Pharmacol Ther 1997; 11:605-12.

108. Gorbach SL. Bismuth therapy in gastrointestinal diseases. Gastroenterology 1990;99:863-75.

109. Tay HP, Chaparala RC, Harmon JW, Huesken J, Saini N, Hakki FZ, et al. Bismuth subsalicylate reduces peptic injury of the oesophagus in rabbits. Gut 1990;31:11-6.

110. Kotzampassi K, Paramythiotis D, Voudouris A, Milias K, Eleftheriadis E. The influence of ranitidine bismuth citrate on rat gastric mucosal microcirculation and adherent mucus gel layer. Ann Gastroenterol 2000;13:118-21

111. Pudlo M, Demougeot C, Girard-Thernier C. Arginase inhibitors: A rational approach over one century. Med Res Rev 2017;37:475-513.

112. Debraekeleer A, Remaut H. Future perspective for potential Helicobacter pylori eradication therapies. Future Microbiol 2018; 13:671-87. 